in 7 edia $\quad \begin{aligned} & \text { InMedia } \\ & \text { The French Journal of Media Studies }\end{aligned}$

8.2. $\mid 2020$

What do Pictures Do? (In)visibilizing the Subaltern

\title{
Women and Gender in Security TV Series
}

March 19-20, 2021, University Panthéon-Sorbonne, DEMOSERIES

\section{Anne Sweet Fédé}

\section{(2) OpenEdition \\ Journals}

Electronic version

URL: https://journals.openedition.org/inmedia/2640

DOI: 10.4000/inmedia.2640

ISSN: 2259-4728

Publisher

Center for Research on the English-Speaking World (CREW)

Electronic reference

Anne Sweet Fédé, "Women and Gender in Security TV Series", InMedia [Online], 8.2. | 2020, Online since 22 October 2021, connection on 28 October 2021. URL: http://journals.openedition.org/inmedia/2640 ; DOI: https://doi.org/10.4000/inmedia.2640

This text was automatically generated on 28 October 2021.

(c) InMedia 


\title{
Women and Gender in Security TV Series
}

\author{
March 19-20, 2021, University Panthéon-Sorbonne, DEMOSERIES
}

\section{Anne Sweet Fédé}

1 The conference "Women and Gender in Security TV Series", which was held over ZOOM on March 19 and March 20, 2021, examined the ways in which women are depicted in security series worldwide. It was hosted at the University Paris 1 Panthéon-Sorbonne by the researchers involved in DEMOSERIES, ${ }^{1}$ a European Research Council project under the direction of Sandra Laugier at the University Paris 1 Panthéon-Sorbonne that is financed by the European Union's Horizon 2020 research and innovation program.

2 The conference is part of a larger DEMOSERIES research project entitled "Shaping Democratic Spaces: Security and TV Series." DEMOSERIES defines the concept of "security series" as "best represented by" shows like 24 (Fox, 2001-2010; 2014) or Homeland (Showtime, 2011-present), which were clearly influenced by $9 / 11$ and the war on terror, but also by "TV series on the history of intelligence and national security, such as The Americans (FX, 2013-2018)" and which "take audiences back to the Cold War era." Superheroes can also be included in the genre of security series, as evidenced by a previous DEMOSERIES conference "Superheroes Over Time" ("Superhéros dans l'air du temps") held on January 12, 2021, which examined the evolution of superheroes in recent series like Jessica Jones (Netflix, 2015-2019) and The Boys (Amazon Prime Video, 2019-present).

3 The objective of the DEMOSERIES project is to study the ways in which security series can offer viewers ideological frameworks for understanding moral and ethical issues and can even shape their understandings of democracy and national security. 24 is a case in point. Influenced by the Republican ideals of its creator Joel Surnow in the wake of 9/11, 24 demonstrated that torture was the solution to "ticking time bomb" situations and necessary to save people from various threats. However, in real life, the US military became concerned that these violent representations-which do not reflect the real way intelligence is obtained from suspects, and the fact that torture is not at all 
effective-were a bad influence on their young soldiers and requested a meeting with the producers of the series to discuss the matter. ${ }^{3}$

4 In examining questions of gender and security in TV series, DEMOSERIES researchers use various approaches and methodologies. It is an interdisciplinary project that includes scholars in its group of core researchers from fields as diverse as philosophy, law, media studies and political science. Scholars from outside the project who are invited to participate in seminars and conferences, like the one on "Women and Gender in Security TV series," also come from various academic disciplines, as well as the professional world (TV critics and TV executives). The DEMOSERIES project is very broad in scope, as the researchers examine not only the esthetics of TV series and how the stories and characters are visualized and represented, but also how the messages are created by series producers and how they are received and understood by viewers as evidenced by their online behaviors. Operating on the premise that TV series can be pedagogical, DEMOSERIES researchers analyze how the series can create "shared and shareable moral values." ${ }^{\prime 4}$ In so doing, they not only concentrate on American media productions, but also have an international and intersectional outlook. A focus seminar on May 11, 2021, for example, on "Africa in Security TV Series" ("L'Afrique dans les séries sécuritaires") covered a subject that is not often studied.

Women in security roles (police officers, secret agents, spies, and superheroes) in popular culture are often seen as empowered and strong: they are violent, capable, and in positions of authority, and their roles both shape and are shaped by societal values. A key example, and one of the most historically significant security heroines on TV and in popular culture, is the character of Wonder Woman, who debuted in the comics 80 years ago during World War II, and was at that time, a symbol of patriotism and heroism, fighting Nazis in a bustier. During the war, she was strong and empowered, even running for president. However, after war ended, and the women who had been working outside the home to support their families, were largely relegated to domestic roles, Wonder Woman changed with the times and became less empowered and more interested in "feminine pursuits" such as modelling and fashion and even worked as a lonely-hearts columnist. In the 1970s, in the wake of the sexual liberation and feminist movements, she shook up the small screen in the TV series Wonder Woman (ABC/CBS, 1975-1979) and was featured on the cover of MS. Magazine, and then again became, a symbol of empowerment in 2017 when she headlined the first big-budget superhero film to be directed by a woman. ${ }^{5}$ Thus, conversations and meanings are created by and about security heroines at each stage of their evolution and existence.

The conference on "Women and Gender in Security TV Series" kicked off with a word from DEMOSERIES' project director Sandra Laugier (University Paris 1 PanthéonSorbonne), who outlined the challenges and difficulties of studying gender in academic settings and the institutional and societal discrimination faced by researchers of this specialized topic. Thus, academics who study gender issues are often confronted with the very same discrimination and sexism as their objects of study. This point of view was echoed by the keynote speaker Geneviève Sellier (Bordeaux-Montaigne University), a pioneer in media and gender studies in France, who started the journal Genre en séries: cinéma, télévision, medias. ${ }^{6}$ In her keynote address, Sellier gave an overview of the representation gender in French series, comparing them to American series, and noting that French lead female heroines would seem to be allowed to be more "real" and have a better work-life balance than their American counterparts, but that youth and 
attractiveness are still valued in female roles, and that much progress still needs to be made in terms of gender representations.

7 Various themes were covered on the agenda, including questions of security, agency, women's strength and stereotypes, with talks like "Women in the Terrorism Series: What Representational Policies?" by Alexis Pichard (Paris Nanterre University), "Borders of the Feminine and Borders of the Nation in Homeland" by Céline Morin (Paris Nanterre University), "The Representation of Women in Cuban Crime Series" by Emmanuel Vincenot (Gustave Eiffel University), "Representations of gender and culture in Queen Solo" by Cécile Accilien, (Kennesaw State University)" and "Gender Terror: The Clash of Men and Women in No man's land" by Thibaut de Saint Maurice (University Paris 1 Panthéon-Sorbonne/DEMOSERIES). The DEMOSERIES project is also interested in the way TV series are created. Thus, the program also included master classes that were led by professionals in the field: "Creating fictions and documentaries series, with La Fémis" (L'École nationale supérieure des métiers de l'image et du son) and "Behind the scenes: women in security television series", both of which offered participants a look at TV series' conception and production.

8 Even if there are still women in security roles in popular culture who save the world while sporting bustiers, female characters have gained much more power and agency, and have become more diverse and intriguing. "The Women and Gender in Security TV Series" conference demonstrates that industries, societies, and popular culture, are mostly evolving in terms of depictions of women on TV, but they are also in flux, and gender representations on screen continue to be perceived as being as meaningful and impactful, especially in light of the fact that sexism, discrimination and backlash are not yet out of the picture-on the screen, behind the scenes, ${ }^{8}$ and for the academics who study them.

\section{NOTES}

1. Use of all-caps conforms to official project title, which is an acronym for the full project name "Shaping Democratic Spaces: Security and TV Series"; "DEMO" also refers to democracy and the questions the project raises about the role TV series play in shaping viewers' perspectives on political and security issues.

2. Project definition on DEMOSERIES' web page, https://www.demoseries.eu/security-series $<$ accessed on May 10, 2021>.

3. This encounter was notably reported on in Jane Mayer, "Whatever It Takes: The Man Behind the Politics of 24", The New Yorker, February 19, 2007, https://www.newyorker.com/magazine/ 2007/02/19/whatever-it-takes <accessed on May 10, 2021>.

4. DEMOSERIES' web page: https://www.demoseries.eu/about <accessed on May 10, 2021>.

5. Wonder Woman (Patty Jenkins, 2017) is considered a cultural and commercial success. See also, Eliana Dockterman, "Wonder Woman Breaks Through", Time Magazine, December 16, 2016, https://time.com/4606107/wonder-woman-breaks-through/ <accessed on May 10, 2021> and Brent Staples, "Wonder Woman Weaponized", The New York Times June 12, 2017, https:// www.nytimes.com/2017/06/12/opinion/wonder-woman-weaponized.html? 
searchResultPosition=15 <accessed on May 11, 2021>. See also Keira V. Williams, Amazons in America: Matriarchs, Utopians, and Wonder Women in U.S. Popular Culture (Baton Rouge: LSU Press, 2019).

6. Available at https://journals.openedition.org/ges/ <accessed on May 10, 2021>.

7. La Fémis is actually an acronym for La Fondation Européenne des Métiers de l'Image et du Son. its former incarnation. It is now referred to as L'École nationale supérieure des métiers de l'image et du son, a French institution of higher education specialized in cinema and TV.

8. Statistics concerning gender parity in front of and behind the camera are compiled by the annual Boxed In study conducted by the Center for the Study of Women in Television and Film at the University of San Diego, https://womenintvfilm.sdsu.edu <accessed on May 10, 2021>.

\section{AUTHOR}

\section{ANNE SWEET FÉDÉ}

Anne Sweet Fédé holds a Master of Arts from Columbia University, and a doctorate from the Université Sorbonne Nouvelle. She is a lecturer in American Civilization and Cinema Studies at the Institut Catholique de Paris, and a contributing editor and member of the editorial board of MAI: Feminism and Visual Culture. Her doctoral research examined the cultural and commercial phenomenon of Girl Power that promoted media products featuring empowered women to young media consumers. In her recent research, she has branched out and begun examining questions of TV addiction, transmedia, fan cultures, intersectionality and fourth-wave feminism. 